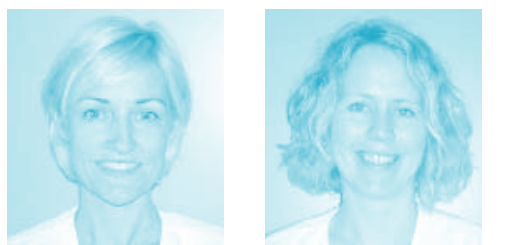

Line Cecilie Steen, spesialsykepleier Kreftsenteret, OUS, Ullevål.
Ragnhild Fossum, spesialsykepleier Gastrokirurgisk avdeling, OUS, Ullevål.
Hilde Knudsrød, høyskolelektor ved Høgskolen i Oslo og Akershus.

\title{
Fagdager økte motivasjonen
}

\author{
Faglig påfyll for sykepleiere som veileder studenter i praksis, \\ $ø$ kte interessen og forståelsen for veillederrollen.
}

denne artikkelen vil vi presentere to samarbeidsprosjekter der vi arrangerte lokale fagdager for kontaktsykepleiere som en forberedelse til at nye studenter kommer til praksisstedet.

\begin{abstract}
Bakgrunn
Praksis er en viktig læringsarena for studenter. I praksis skal studentene lære ferdigheter, integrere kunnskap og utvikle holdninger. Studentveiledning er en viktig del av praksisperioden. I Rammeplan for sykepleierutdanning heter det at studentene skal ha jevnlig veiledning, oppfølging og vurdering i praksisperioden. Videre heter det at «veiledere må ha kompetanse til å veilede studentene og å vurdere deres faglige utvikling, herunder også etiske aspekter ved yrkesutøvelsen samt skikkethet» (1, s. 11). Praksisstedets sykepleiere har ansvar for daglig veiledning og opplæring Vår erfaring er at mange sykepleiere mangler den veiledningskompetansen som kreves, og at motivasjonen for å veilede studenter varierer. Mange opplever ansvaret som stort og er usikre på hva
\end{abstract}

\section{Hovedbudskap}

Samarbeid mellom høyskole og praksisfelt om lokale fagdager for kontaktsykepleiere har vist seg å være et godt redskap for å gjøre sykepleiere mer motiverte og bedre rustet til praksisveiledning.

\section{Søkeord}

Les mer og finn litteraturhenvisninger på våre nettsider. , Sykepleierstudent / Praksis / Veiledning og hvordan studenter skal lære i praksis.

Dette var utgangspunktet for to samarbeidsprosjekter mellom Oslo universitetssykehus, representert ved Kreftsenteret og Gastrokirurgisk sengepost på Ullevål, og Fakultet for helsefag ved Høgskolen i Oslo. Bakgrunnen for slike samarbeidsprosjekter er en omdisponering av praksisveiledningsmidlene, hvor midlene som praksisstedet tidligere ble tildelt for å ha studenter nå skal benyttes til prosjekter eller særskilte tiltak som fremmer samarbeid mellom utdanningsinstitusjonene og praksisstedene.

Målet med fagdagen var at deltakerne skulle bli tryggere og mer motiverte for rollen som kontaktsykepleier, og få økt kunnskap og forståelse for hva veiledning er og handler om. Gjennom å styrke veiledningskompetansen og skape bevissthet om veilederrollen ønsket vi å gjøre kontaktsykepleierne mer motiverte og kompetente til oppgaven som praksisveiledere. Vi ville også gi kontaktsykepleierne noe tilbake for innsatsen de gjør som veiledere. Mange legger ned mye arbeid i denne oppgaven, og vi ønsket å tilby faglig påfyll i rammer som innbyr til inspirasjon.

\section{Gjennomføring}

Fagdagene har vært arrangert like før praksisstart, eller i første uken av praksisperioden. Antall deltakere har variert mellom fire og ti sykepleiere. Totalt har det vært arrangert 12 fagdager. Den første fagdagen ble holdt på Gastrokirurgisk sengepost våren 2009. Dette er en studenttett post, som mottar bachelorstudenter fire ganger i året. Sykepleierne på denne avdelingen er forholdsvis unge, både med hensyn til alder og erfaring som sykepleiere. På Kreftsenteret er det arrangert fagdager for kontaktsykepleiere siden januar 2010. Senteret mottar studenter flere ganger i året, både bachelorstudenter og studenter som tar videreutdanning i kreftsykepleie. Mange av sykepleierne som jobber her har lang erfaring, både som sykepleiere og praksisveiledere.

Innholdet i fagdagene er organisert ut ifra et læringssyn hvor dialog og egenaktivitet er sentralt. Likevel er det faglige opplegget noe forskjellig på de to avdelingene, ettersom sykepleiergruppens erfaringsbakgrunn er ulik. Både på Gastrokirurgisk sengepost og Kreftsenteret blir det lagt vekt på at fagdagen skal ha en avslappet stemning. Det blir servert god mat og lagt inn godt med pauser i programmet. Fagdagene er godkjent av NSF som meritterende for godkjenning til klinisk spesialist i sykepleie eller spesialsykepleie.

\section{På Gastrokirurgisk sengepost}

Fagdagen er delt i to. I første del fokuserer vi på strukturerte temaer innen praksisveiledning: Veilederrollen og maktforholdet i veiledningsrelasjonen, hvordan vi kan gjøre studenten mottakelig for veiledning og forslag til hvordan kontaktsykepleier kan organisere dagene i praksisperioden. Formelle krav og forventninger som stilles til studenter, kontaktsykepleier og lærer, samt studentenes studiekrav i den aktuelle perioden, blir også diskutert. Både kompetansekrav, for at studentene skal få bestått praksis, og formaliteter og utfordringer rundt «ikke bestått» blir gjennomgått og konkretisert. Vi diskuterer også etiske aspekter rundt hvor og hvordan vi snakker om studentsituasjoner, spesielt når det oppstår noe som er vanskelig. Etter lunsj er det en mer uformell del hvor vi diskuterer konkrete veiledningssituasjoner, og 


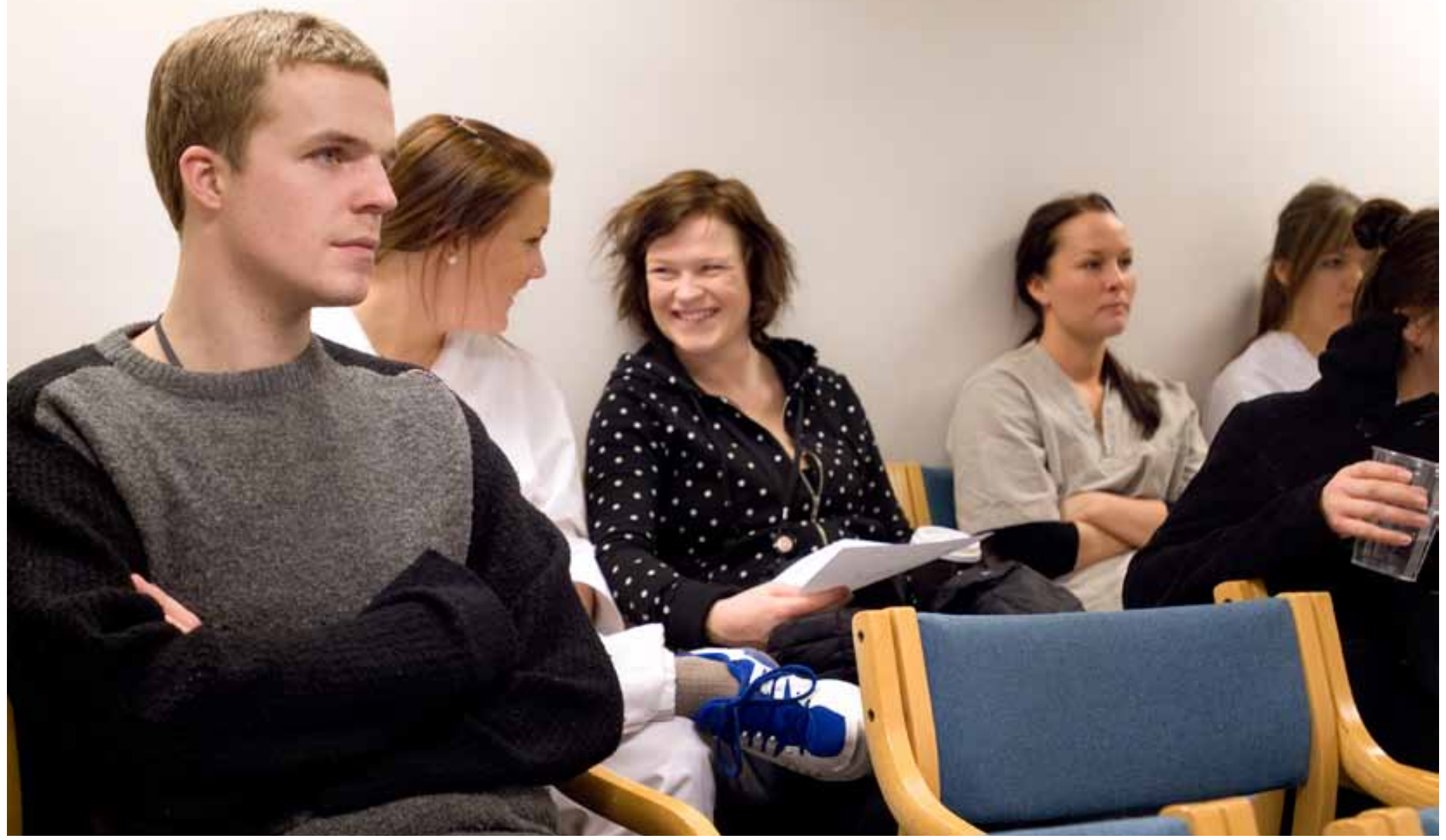

NYTTIG: Mange kontaktsykepleiere trekker frem betydningen av å utveksle erfaringer med hverandre og diskutere utfordringer rundt det å være kontaktsykepleier. Arkivfoto: Stig Weston.

hvordan vi kan gi tilbakemeldinger på en god måte. Erfaringer med å ha og å være student blir også diskutert.

\section{På Kreftsenteret}

På Kreftsenteret er fagdagen bygd opp rundt fire hovedtemaer: 1) Veiledningens hva og hvordan, 2) relasjon og kommunikasjon i veiledning, 3) planlegging, gjennomføring og evaluering av en praksisperiode, 4) vurdering av studenter i praksis.

Deltakerne på fagdagen kommer fra ulike avdelinger på senteret og er ikke nødvendigvis så godt kjent med hverandre. Vi organiserer derfor dagen ut fra hvordan en praksisperiode kan organiseres: En bli kjent-fase, en arbeidsfase, og en avslutningsfase. Vi starter med å bli kjent gjennom praktiske øvelse og trekker paralleller til hvordan vi kan møte studentene når de starter praksisperioden. Betydningen av et godt første møte, hvor man føler seg velkommen og sett, for å skape trygghet og tillit, blir diskutert. I arbeidsfasen jobber vi med de fire hovedtemaene for dagen. I tillegg til den tematiske undervisningen benytter vi oss av ulike arbeidsformer som rollespill og skriftlige oppgaver for å skape aktivitet, deltakelse og dialog. Det blir satt av god tid til refleksjon og diskusjon underveis. I avslutningsfasen oppsummerer vi dagen og hvilken betydning den har for praksis.

\section{Deltakernes evalueringer}

Evaluering har vært en viktig del av prosjektene. Kontaktsykepleierne har evaluert fagdagene både skriftlig og muntlig, og tilbakemeldingene har generelt vært positive. Det er tre forhold som særlig er blitt trukket frem: Kontaktsykepleierne føler seg bedre forberedt til oppgaven, mer motivert for å ha student, og tryggere i rollen som veileder. Eksempler på tilbakemeldinger er: «Gjør meg mer forberedt. Setter i gang tanker rundt det å være veileder, hva det vil si og hvilket ansvar det er», «Føler meg mer trygg i rollen som veileder», «Bedre forberedt og motivert til å ha student», «Fint med bevisstgjøring av rollen som kontaktsykepleier. Er foreløpig det eneste forum hvor vi samlet kan diskutere rollen». I evalueringene kommer det tydelig frem at det er et behov for å ha slike fagdager: «Alle sykepleiere som er veiledere bør ha denne fagdagen. Burde vært obligatorisk», «Det var en nyttig og lærerik dag og den bør prioriteres».

Mange trekker frem betydningen av å utveksle erfaringer med hverandre og diskutere utfordringer rundt det å være kontaktsykepleier. Det blir også trukket fram som positivt at det er en liten

\section{«Alle sykepleiere som er veile- dere bør ha denne fagdagen.»}

gruppe, noe som gjør det lettere for alle å delta aktivt. Et annet viktig punkt i evalueringen har vært betydningen av at læreren fra høyskolen også har deltatt på fagdagene. Tilbakemeldingene viser at det blir lettere å ta kontakt med læreren for å diskutere veiledningen av studenten senere, og at det er fint å kunne stille læreren spørsmål på fagdagen: «Føler meg mer sikker på at lærer fra $\mathrm{HiO}$ er en person man kan ta opp ting med», «Ser at det er et godt samarbeid mellom avdelingen og HiO-lærer. Viktig!», «Lett å ta kontakt med lærer for å ta tak i ting i forhold til studenten». Studentene har også gitt tilbakemeldinger som støtter vår oppfatning av at fagdagene bidrar 


\section{Sykepleierutdanning}

til en god praksisperiode: «Merker at avdelingen var forberedt på å ta imot oss», «Kontaktsykepleierne visste hva vi skulle igjennom».

\section{Suksess}

Samarbeidet mellom avdelingene og utdanningsinstitusjonen har vært en viktig suksessfaktor for prosjektene. Vi opplever at det stilles stadig større krav til kontaktsykepleierne, samtidig som høyskolelærerne er mindre i praksisfeltet. Derfor kan samarbeidsprosjekter som dette være med på å gjøre gapet mellom utdanningsinstitusjonen og praksisfeltet mindre. Vi har gjennom samarbeidet blitt bedre kjent med den virkeligheten vi begge befinner oss i, og dette har vært nyttig for å tilpasse innholdet i fagdagene. Slik det framkommer av evalueringene, har også høyskolelærers tilstedeværelse på fagdagene blitt trukket frem som positivt. Samme høyskolelærer har vært knyttet til Gastrokirurgisk sengepost over tid, og har observert at sykepleierne tar med seg det de har lært på fagdagene og praktiserer det i veiledningen av studentene. Eksempler på dette er at sykepleierne er blitt tydeligere og modigere i sine tilbakemeldinger, tilbakemeldingene er blitt mer strukturerte og problemer blir grepet fatt i tidligere.

\section{Tilpasset innhold}

Ved å holde fagdagene lokalt, kan vi tilpasse innholdet til sykepleierne på den enkelte arbeidsplass. Sykepleierne på Kreftsenteret og Gastrokirurgisk sengepost skiller seg fra hverandre ved at den ene avdelingen har flere nyutdannete sykepleiere uten veiledningserfaring, enn den andre. Vi har derfor lagt opp fagdagene noe ulikt for at nivået skal passe deltakerne. Dette har vært en positiv erfaring. En annen styrke ved å holde fagdagene lokalt, har vært at de kan knyttes direkte opp mot en praksisperiode. Innholdet oppleves da som svært relevant og aktuelt for deltakerne, og de får praktisert det de lærer umiddelbart etterpå.

Det er en utfordring for praksisfeltet å få sendt sykepleiere på veiledningskurs. Prosjektet har ikke dekket utgiftene for å fristille sykepleiere til å delta på fagdagen, det har den enkelte avdeling selv bekostet. Det er derfor en stor fordel for praksisfeltet selv å kunne velge tidspunkt for fagdagen. Det oppleves også som en styrke at flere kontaktsykepleiere får delta på samme fagdag, så kontaktsykepleierne får en felles forståelse av hvordan de kan veilede studenter i praksis. Vår erfaring er at når rammene for fagdagen først er på plass går selve gjennomføringen av dagen lett.

\section{Avslutning}

Kunsten å veilede studenter i praksis er ikke lært på en dag. Våre fagdager for kontaktsykepleiere kan ikke erstatte veiledningskurs og utdanninger innen praksisveiledning. Fagdagene kan imidlertid være et viktig supplement som gjør sykepleierne bedre forberedt til den viktige oppgaven det er å veilede studenter. Fagdagen gir sykepleierne en innføring i studentveiledning, og motiverer dem til oppgaven.

Samarbeidet mellom avdelingene og utdanningsinstitusjonen har gjort at vi har dratt nytte av hverandres kunnskap og erfaringer. Vi har erfart at enkle grep hadde god effekt. Vi håper derfor våre erfaringer kan inspirere andre til å samarbeide om lignende opplegg. Tilbakemeldinger som "«jenner jeg har lyst til å fordype meg mer i veilederrollen» styrker vår tro på at fagdagene er nyttige. IIII

\section{LITTERATUR}

Rammeplan for sykepleierutdanning. Kunnskapsdepartementet 25. januar 2008.

Fagartikler kan sendes til torhild.apall@sykepleien.no 